\title{
Hegemoni dan Simbol Daerah
}

\author{
Dwiyana Habsary ${ }^{(1) a}$, Sudjarwo(2)b
}

(1) Pend. Bahasa dan Sastra Fakultas Keguruan dan IImu Pendidikan Universitas Lampung

(2) Magister Pendidikan IPS Fakultas Keguruan dan IImu Pendidikan Universitas Lampung

email korespondensi: a habsarydwiyana@gmail.com, ${ }^{b}$ profdrsudjarwo@gmail.com

\begin{abstract}
Lampung Province is an area that has unique characteristics. One of the uniqueness of this area is the existence of two customs that inhabit certain areas of the province. The two customary territories have their respective symbols that are used to characterize these regions. These symbols are considered 'important' to be preserved. This assumption led to the existence of policies that were made and applied in this area. Some of these symbols are Siger, art motifs and regional pop songs. This research describes how the efforts of the regional government introduce these symbols. Which layer of society is affected by the 'impact' of the policy. The research method used is a qualitative method. The approach used is socio-anthropology. The data collected uses several methods such as literature studies, interviews, and documentation. The results of this research show that the government uses its power to introduce symbols as regional identities. The power is realized by making a Regional Regulation (Regional Regulation), which was made by the Governor, as well as several appeals made by the Mayor.
\end{abstract}

Keyword: hegemony, symbol, tradition

\begin{abstract}
ABSTRAK. Provinsi Lampung merupakan daerah yang memiliki karakteristik yang unik. Salah satu keunikan daerah ini adalah adanya dua adat yang mendiami wilayah-wilayah tertentu provinsi ini. Kedua wilayah adat tersebut memiliki simbol masing-masing yang dijadikan ciri wilayah-wilayah tersebut. Simbol-simbol tersebut dianggap 'penting'untuk dilestarikan. Asumsi tersebut menyebabkan adanya kebijakan-kebijakan yang dibuat dan diterapkan di daerah ini. Beberapa simbol tersebut adalah Siger, motif seni rupa dan lagu-lagu pop daerah. Penelitian ini memaparkan bagaimana upaya pemerintah daerah mengenalkan simbol-simbol tersebut. Lapisan masyarakat mana sajakah yang terkena 'imbas' dari kebijakan tersebut. Metode penelitian yang dilakukan adalah metode kualitatif. Adapun pendekatan yang digunakan adalah sosio-antropologi. Adapun data yang dikumpulkan menggunakan beberapa metode seperti studi pustaka, wawancara, dan dokumentasi. Hasil dari penilitian ini menunjukkan bahwa pemerintah menggunakan kekuasaannya untuk mengenalkan simbol sebagai identitas daerah. Kekuasaan tersebut diwujudkan dengan cara membuat sebuah PERDA (Peraturan Daerah), yang dibuat oleh Gubernur, serta beberapa himbauan yang dibuat oleh Walikota.
\end{abstract}

Kata kunci: hegemoni, simbol, tradisi

1. Pendahuluan

Fenomena dominasi kekuasaan pada kebijakan-kebijakan yang ada di suatu daerah dapat dilihat di seluruh wilayah. Artikel ini akan memaparkan tentang fenomena yang terjadi di daerah Lampung. Paparan yang mengangkat bagaimana pemerintah daerah menggunakan kekuasaan dengan menghasilkan kebijakan yang dianggap mendukung pelestarian budaya daerah Lampung. Alur ini yang menjadi pusat perhatian dari artikel ini. Penekanan pada bentuk-bentuk kebijakan yang dihasilkan, serta bagaimana penerapannya. Selain bentuk kebijakan, deskripsi tentang lapisan mana saja yang terkena 'imbas'dari kebijakan tersebut akan dijelaskan pula.

Kebijakan tersebut sebagian besar merupakan hasil dari nilai yang dipegang secara turun-temurun sebanyak 3 generasi [1]. Nilai tersebut diwujudkan dalam beberapa kesepakatan bersama tentang hal-hal yang disepakati untuk memperoleh sebuah pengakuan. Pengakuan 
tersebut didapat dari masyarakat sekitar yang memiliki kesepahaman yang sama. Di daerah Lampung nilai puncak yang dapat diperoleh seseorang dalam bermasyarakat adalah pi'il. Pi'il merupakan falsafah hidup masyarakat Lampung yang merupakan bagian yang menyatu dalam kehidupan sehari-hari.

Pi'il selain dikatakan sebagai falsafah hidup, juga merupakan identitas budaya masyarakat Lampung dalam bersosialisasi. Identitas ini dibangun dan dibentuk oleh masyarakat pendukungnya [2]. Hal tersebut sesuai dengan apa yang disampaikan oleh Abdullah [3] tentang kontruksi identitas. Pi'il tidak semata-mata lahir begitu saja di kalangan masyarakat Lampung namun dibangun dan dibentuk oleh masyarakat Lampung melalui nilai-nilai budaya yang mendukung pi'il tersebut. Adapun nilai-nilai tersebut adalah sakai sambayan, nemui nyimah, nengah nyappur, bejuluk beadek, pi'il pasenggiri.

\section{Metode Penelitian}

Penelitian ini merupakan sebuah kajian budaya yang bersumber pada data-data yang dihasilkan dari proses studi pustaka, wawancara, dan dokumentasi. Studi pustaka yang dilakukan adalah dengan mencari seluruh referensi yang terkait dengan fenomena kebijakan. Selain fenomena kebijakan, referensi tentang teori dan pendekatan yang digunakan juga merupakan fokus dari studi pustakan yang dilakukan. Adapun dokumentasi yang digunakan dalam penelitian ini adalah dengan cara melancak bukti fisik dari kebijakan dan PERDA yang terdapat di daerah Lampung. PERDA dan himbauan yang dihasilkan oleh pemimpin daerah Lampung kemudian diklasifikasikan. Klasifikasi tersebut berdasarkan kesesuaian dengan simbol-simbol yang ada di daerah Lampung.

Artikel ini menekankan pada metode kualitatif, untuk itu diperlukan proses triangulasi data. Triangulasi data ini berupa konfirmasi ulang suatu data dengan cara mengecek kembali kevalidan berdasarkan tiga tahap pengumpulan data (studi pustaka, wawancara, dan dokumentasi). Jika proses itu memperoleh kesesuaian maka suatu data dapat digunakan untuk bahan laporan dan menunjukkan, bahwa data yang diperoleh valid. Hal ini dilakukan agar hasil penelitian ini benarbenar didukung dengan bukti yang kuat. Bukti-bukti tersebut bukan sekedar asumsi-asumsi belaka atau opini-opini publik yang berkembang di daerah Lampung.

Adapun teori yang digunakan adalah teori hegemoni. Pengertian hegemoni adalah memimpin, kepemimpinan, kekuasaan yang melebihi kekuasaan yang lain. Secara umum hegemoni adalah sebagai suatu dominasi kekuasaan suatu kelas sosial atas kelas sosial lainnya, melalui kepemimpinan intelektual dan moral yang dibantu dengan dominasi atau penindasan. Hegemoni dapat pula diartikan sebagai dominasi oleh suatu kelompok terhadap kelompok yang lain, dengan atau tanpa ancaman kekerasan, sehingga ide-ide yang didiktekan oleh kelompok dominasi terhadap kelompok yang didominasi/kuasai diterima sebagai suatu hal yang wajar dan tidak mengekang pikiran. Hegemoni yang digunakan pada artikel ini lebih pada teori yang dipaparkan oleh Gramsci [4] yang lebih menekankan pada kepemimpinan moral, walaupun dalam fenomena sesungguhnya tampak pula hegemoni Marxis yang menekankan pada 'dominasi kelas'. Kedua konsep ini dikombinasikan dan ditempatkan pada 
fenomena-fenomena yang sesuai dengan fakta lapangan penelitian.

\section{Hasil Penelitian}

Kondisi masyarakat Lampung yang dilihat dari kacamata adat menunjukkan dua kondisi budaya. Kondisi tersebut adalah hal-hal tertentu menjukkan 'berlawanan', namun ada pula yang menunjukkan kesamaan. Berlawanan ditunjukkan dengan cara memperoleh gelar adat. Pada masyarakat Pepadun, gelar adat dapat 'diperjual'belikan. Sedangkan pada masyarakat Saibatin, gelar adat dapat diperoleh hanya berdasarkan garis keturunan. Kondisi tersebut dapat dipastikan, bahwa masyarakat adat mana yang dapat 'mendominasi' di wilayah Provinsi Lampung. Fakta adanya dua masyarakat adat ini menunjukkan bahwa dinamika masyarakat secara adat tidak akan pernah berhenti. Fakta tersebut didukung pula dengan kondisi masyarakat Lampung yang diwarnai pula dengan pendatang.

Fakta yang menunjukkan pluralisme dan multikultural inilah yang menyebabkan kondisi budaya Lampung yang tidak bisa dikondisikan secara 'homogen'. Fakta tersebut pula menunjukkan tidak adanya kebenaran mutlak secara kultural, sebagaimana yang dipaparkan oleh Marxis yang menjunjung tinggi kebenaran mutlak. Konsep Gramsci jjustru menunjukkan adanya negosiasi budaya yang dinamis. Negosiasi tersebut dilakukan dengan cara membangun issue-issue yang didukung secara terpusat.

Fenomena yang selalu digaungkan di negara adalah konsep 'Tunggal Ika' dengan cara menegaskan dan mengokohkan jargon ' NKRI Harga Mati!'. Sementara kondisi tersebut sebenarnya bertolak belakang dengan adanya kebijakan 'otonomi daerah'.
Masing-masing daerah diberi 'kelonggaran' untuk mengembangkan dan mengedepankan kemampuan dan ciri dalam menjalankan pemerintahan daerah masing-masing. Issue keberagaman atau 'Kebhinekaan' yang sesungguhnya menjadi fakta yang terjadi di lapangan menjadi hal atau sesuatu yang harus dibatasi diamikanya. Adapun cara yang ditempuh oleh pemerintah daerah adalah dengan cara mengeluarkan PERDA dan himbauan. Kondisi ini yang ditekankan oleh Gramsci bahwa konsep atau ideologi tidak otomatis tersebar dalam masyarakat, melainkan harus diciptakan melalui kepemimpinan atau lembaga tertentu yang dijadikan sebagai pusat dan disepakati bersama.

Salah satu yang dapat dijadikan contoh adalah adanya PERDA Lampung Nomor 27 Tahun 2014 tentang 'Arsitektur Bangunan Gedung Berornamen Lampung'. Dalam PERDA tersebut ditarakan terlebih dahulu semacam konsep atau ideologi yang sifatnya menanamkan sesuatu atau doktrinasi. Pengantar tersebut sebagai berikut [5]:

‘...bahwa Budaya Lampung merupakan bagian budaya bangsa Indonesia dan sebagai aset nasional yang keberadaannya perlu diberdayakan dan dilestarikan, sehingga dapat berperan dalam memperkokoh jati diri dan akar budaya bangsa...'

Kutipan di atas menunjukkan bahwa adanya tujuan yaitu untuk melestarikan budaya, maka perlu cara. Cara yang ditempuh adalah dengan 'memberdayakan' budaya Lampung yang merupakan bagian dari budaya bangsa. Tujuan besarnya adalah memperkokoh jati diri dan akar budaya bangsa. Upaya tersebut tidak hanya berhenti pada bangunan atau ornamen 
yang berdasarkan budaya Lampung. Penyebutan tempat dan huruf-huruf yang dituliskan juga harus menggunakan aksara Lampung, yaitu aksara 'ka ga nga".

Adapun elemen yang menjadi bagian dari sebuah bangunan adalah Siger. Penjelasan tentang Siger dalam PERDA tersebut adalah sebagai berikut:

‘...Siger adalah elemen bangunan yang berbentuk Siger (mahkota).'

Penjelasan selanjutnya adalah tentang ketentuan penggunaan elemen bangunan yang harus disertakan pada bangunan-bangunan terutama yang berada disepanjang jalan protokol di daerah Lampung.

'Elemen bangunan sebagaimna dimaksud pada ayat (1) merupakan bagian pada bangunan yang bentuk dan penggunaannya perlu memperhatikan ketentuan dan nilai-nilai adat setempat yang berlaku pada masyarakat Lampung.'

Peratuan tersebut menunjukan bahwa penggunaan ornamen-ornamen yang dianjurkan untuk digunakan salah satunya adalah Siger. Pengunaan Siger tersebut dapat dilihat pada ruang-ruang publik yang ada di daerah Lampung. Siger-siger yang dapat dilihat di ruang publik adalah Siger yang dimiliki oleh adat Pepadun dan Saibatin. Berikut ini adalah beberapa contoh penggunaan ornamen Siger di ruang publik yang ada di daerah Lampung.

Gambar 1 menunjukkan tugu pengantin dari adat Saibatin. Pada masyarakat Saibatin warna yang dominan adalah warna merah. Siger yang dipakai oleh pengantin wanita adat Saibatin memiliki lekuk 7 . Lekuk 7 tersebut melambangkan jumlah Kepaksian yang ada di masyarakat Saibatin. Adapun lekuk 9 yang terdapat pada Siger masyarakat Pepadun bermakna Marga yang terdapat di adat Pepadun. Ragam hias yang digunakan pada bagian bawah tugu tersebut adalah motif perahu. Hal ini menggambarkan kehidupan dan wilayah pemukiman masyarakat Saibatin yang berada di Pesisir Provindi Lampung. Wilayah Pesisir Lampung masyarakatnya bergantung dengan hasil laut dan menjadi pusat perekonomian masyarakat adat Saibatin.

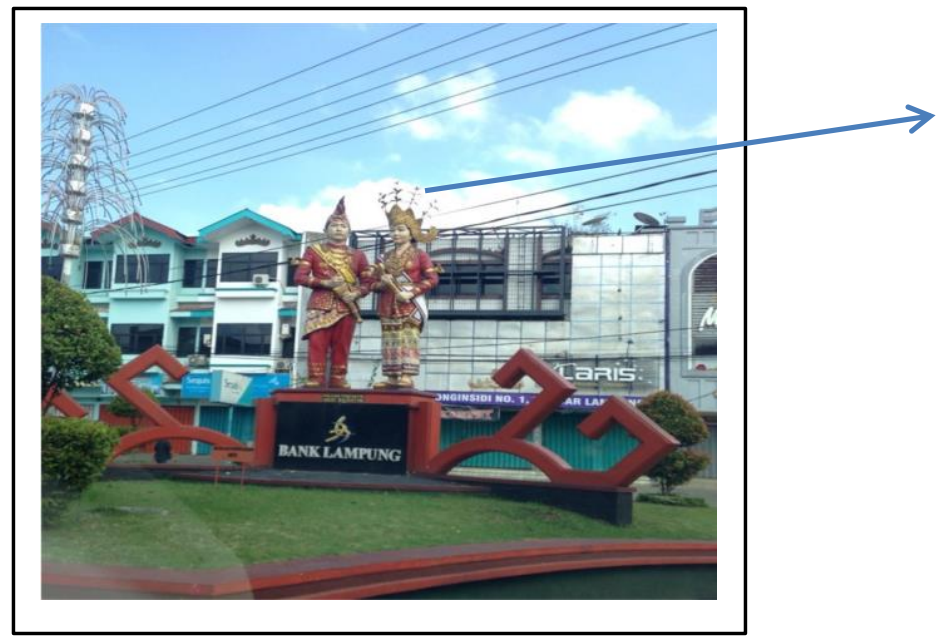

Siger yang berasal dari adat Saibatin. Ditunjukkan dengan lekuk yang berjumlah 7 .

Gambar 1. Tugu Pakaian Adat Saibatin di Ruang Publik kota Bandar Lampung [6] 


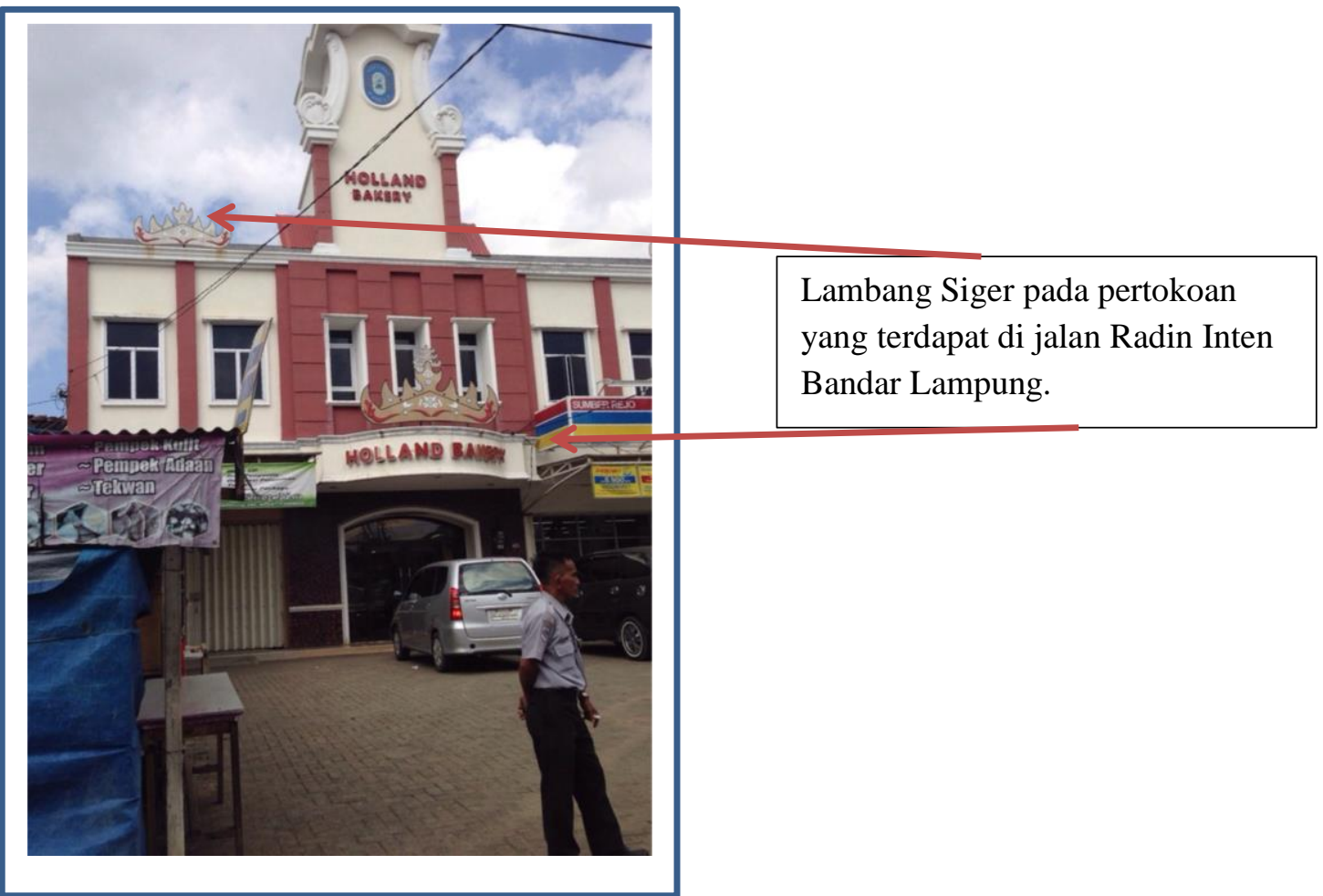

Gambar 2. Siger pada Pertokoan di Daerah Lampung [6]



Gambar 3. Lambang Daerah Lampung [7]

Gambar 2 menunjukkan partisipasi masyarakat Bandar Lampung terhadap surat edaran yang dikeluarkan oleh Walikota Lampung. Partisipasi tersebut ditunjukkan dengan memasang simbol Siger yang diletakkan di dinding ruko. Partisipasi ini menunjukkan bahwa kesadaran masyarakat Lampung tentang simbol daerah Lampung. Kesadaran tersebut ditunjukkan dengan jumlah lekuk yang ada menunjukkan pada Siger slah satu wilayah adat Lampung.

Penjelasan dari Lambang Lampung (Gambar 3) terdiri dari lukisan padi dan lada yang merupakan simbol hasil bumi yang banyak terdapat di Lampung. Landuk dan payan berupa golok dan tombak adalah senjata tradisional masyarakat Lampung. Gong 
merupakan simboldemokrasi. Siger sebagai lambang keagungan budaya. Payung adalah tempat masyarakat berlindung. Pada lambang, terdapat tulisan Sang Bumi Ruwai Jurai yang berarti rumah tangga yang agung bahagia dua golongan masyarakat (ruwai dan jurai) yang terdapat pada masyarakat asli dan pandatang.

Arti dan makna lambang propinsi Lampung. Gambar dan lambang daerah Lampung mempunyai design yang sangat unik dan menarik serta memiliki sarat dengan pralambang yang menjadi identitas daerah lampung. Seperti simbol daun dan buah lada yang ada didalamnya, setangkai padi, siger dan gong. Semuanya memiliki arti dan makna yang menjadi manifestasi dari budaya daerah lampung.

Komponen paling mendasar dari lambang daerah lampung adalah pada perisai bersegi lima, tombak dan golok, siger, gong, payung, daun, buah lada, setangkai padi, dan pita yang bertuliskan kata "Sang Bumi Ruwa Jurai". Masing-masing simbol memiliki arti dan makna yang sangat mendalam. Berikut ini adalah artikel tentang arti dan makna simbol pada lambang provinsi lampung.

Arti dan makna simbol pada Lambang daerah Lampung.

\section{Bingkai Perisai Bersegi Lima}

Perisai bersegi lima adalah mengambarkan tantang kesanggupan untuk mempertahankan dan menjalankan cita-cita dan tujuan luhur membangun daerah lampung untuk mencapai masyarakat yang adil dan makmur berdasarkan pancasila.

\section{Kata Lampung}

Kata Lampung itu sendiri merupakan sebuah penegasan untuk menunjukan identitas pemilik lambang lampung tersebut.

3. Warna

Lambang lampung sendiri terdiri dari berbagai perpaduan warna yang memiliki arti dan makna:

Warna Hijau melambangkan dataran yang tinggi dan subur untuk menanam tanamam keras dan tanaman musiman.

Warna Coklat melambangkan pada dataran rendah yang subur untuk diranami sawah dan ladang.

Warna Biru melambangkan kekayaan sungai dan lautan yang merupakan sumber dari perikanan dan kehidupan para Nelayan di lampung.

Warna Putih melambangkan kesucian hati dan keikhlasan hati masyarakat lampung. Warna Kuning (tua, emas dan muda) melambangkan sebuah keagungan dan kejayaan dan kebesaran cita-cita masyarakat lampung untuk membangun daerah dan Negaranya.

\section{Payung}

Payung berwarna kuning tersebut bermakna ganda yaitu payung agung yang melambangkan Negara Republik Indonesia (RI) dan sebagai payung jurai (masyarakat) yaitu melambangkan Provinsi.

\section{Kesimpulan Dan Saran}

Simbol seni yang terdapat di daerah bisa dikatakan menjadi 'umum' diketahui masyarakat Lampung, Bandar Lampung khususnya berkat upaya pemerintah daerah setempat. Upaya yang dilakukan salah satunya melalui PERDA dan surat-surat edaran yang berisi kebijakan yang berpihak pada daerah Lampung. Keberpihakan ini menjurus pada seni 
tradisional daerah Lampung. Upaya saat ini yang sangat kentara sekali pada bagian seni rupa. Seni rupa tersebut disosialisasikan dalam bentuk seni rupa terapan.

Upaya yang digambarkan di atas menunjukkan peran nyata pemerintah daerah. Peran tersebut melalui ranah 'polirik' yang saat ini dapat dengan nyata dilihat keberhasilannya. Politik di sini bukan dalam arti partai atau ranahranah yang berhubungan dalam PEMILU, tetapi lebih menekankan pada pemerintahan. Pemerintahan yang menggambarkan kekuasaan atau sekelompok orang yang tergolong dalam organisasi pemerintahan yang memiliki 'kuasa' ada kebijakankebijakan. Kebijakan-kebijakan inilah yang dapat digunakan dalam mengangkat keberadaan simbol-simbol seni yang ada di daerah Lampung.

Efektivitas menggunakan PERDA dan kekuasaan dalam menerapkan sesuatu bisa dikatakan sangat baik di daerah Lampung. Kondisi ini diperlukan untuk menjaga keberadaan seni tradisional daerah Lampung di tengah maraknya gempuran budaya asing. Gempuran tersebut bisa dikatakan saat ini dari seluruh aspek kehidupan masyarakat Lampung terutama seni. Upaya yang dilakukan pemerintah daerah ini dilakukan untuk masyarakat Lampung. Masyarakat Lampung secara tidak sadar 'dibiasakan' untuk melihat simbol-simbol yang dimiliki oleh Lampung dan menjadi warisan budaya yang harus dijaga.

Selain upaya untuk mengenalkan kepada masyarakat, upaya ini juga dilakukan untuk menumbuhkan rasa keLampungan-an seseorang. Menjadi 'orang Lampung' tidak hanya tinggal dan hidup di Lampung, tetapi juga mengetahui budaya-budaya yang terdapat di daerah Lampung, salah satunya dengan mengetahui simbol- simbol seni yang dimiliki daerah Lampung. Hal ini dapat bertujuan untuk menjaga ke-Lampung-an bagi masyarakat 'asli' Lampung, baik masyarakt adat Pepadun maupun masyarakat adat Saibatin.

Pemahaman tentang simbol seni seolah-olah tidak hanya berupa mengetahui sebatas makna saja, melainkan seolah mencapai pada gaya hidup. Gaya hidup di sini dimaksudkan dengan mengupayakan pembiasaan bagi masyarkat Lampung. Salah satunya adalah dengan membiasakan membuat gapura selalu menghadirkan motif-motif ragam hias Lampung. Bahkan saat ini tidak hanya menekankan pada ranah artefak saja atau seni yang mewujud. Seni yang diupayakan dikenalkan oleh pemerintah daerah Lampung adalah seni suara. Upaya yang dilakukan oleh pemerintah daerah Lampung adalah melalui PERDA untuk memutar lagu daerah Lampung pada jam-jam tertentu (saat makan siang). Hal ini menunjukkan bahwa pengenalan tersebut merambah pada seluruh aspek seni yang dapat dengan mudah dinikmati dan tanpa sadar masyarakat nantinya akan terbiasa dengan hal-hal yang merupakan bagian dari warisan budaya daerah Lampung.

\section{Saran}

Upaya pemerintah daerah Lampung yang sudah dilakukan hingga saat ini walau bisa dikatakan berhasil dan efektif, namun masih saja ada beberapa catatan. Catatan tersebut cenderung lebih bersifat dalam menyediakan rang komunikasi. Ruang komunikasi ini bukan dalam arti komunikasi pemerintah dan masyarakat, tetapi komunikasi antara masyarakat dan simbol-simbol tersebut. Komunikasi ytang dimaksudkan adalah adanya 
komunikasi dengan simbol seni yang telah diupayakan untuk dikenal oleh masyarakat Lampung. Hal ini dapat diwujudkan salah satunya dengan dibuatnya pusat-pusat berkesenian yang melibatkan masyarakat umum.

Adanya 'komunikasi' masyarakat dengan simbol-simbol seni yang ada di sebuah ruang karya dapat meningkatkan kesadaran masyarakat Lampung akan pentingnya menjaga simbol-simbol yang dimiliki. Hal ini bertujuan untuk memberikan pengetahuan pada masyarakat mana 'ruang' yang perlu dijaga, dan mana 'ruang' yang dapat membuka dan memberi kebebasan masyarakat dan berkreativitas. Hal ini dilakukan agar tidak terjadi kondisi yang dikhawatirkan oleh ketua adat yang ada di daerah Lampung. Kekhawatiran tersebut adalah tercerabutnya akar-akar seni budaya Lampung, sehingga menyebabkan sulitnya untuk mengetahui keaslian seni dan budaya Lampung.

Kebijakan-kebijakan yang ditempuh melalui peraturan daerah dapat diberlakukan juga untuk menjaga kondisi yang tidak diharapkan terjadi. Peran pemerintah memang harus digunakan dalam menjaga kebudayaan daerah. Hal ini menjadi sebuah dasar dalam menjaga 'kelanggengan' sebuah identitas budaya. Adanya 'kekuatan' dalam menjaga dan menerapkan sebuah perubahan atau sesuatu yang memerlukan proses yang continue. Dasar dari sebuah eksistensi simbol tidak hanya dibutuhkan sebuah doktrinasi tetapi juga peran yang berlangsung secara berkesinambungan.

\section{Daftar Pustaka}

[1] E. Shils, Tradition. Chicago: The University of Chicago, 1981.

[2] C. Baker, Cultural Studies. Yogyakarta: Kreasi Wacana, 2016.

[3] I. Abdullah, Konstruksi dan Reproduksi Kebudayaan. Yogyakarta: Pustaka Pelajar, 2015.

[4] Anonymus, "Konsep Hegemoni Gramsci," https://id. wikipedia.org/wiki/Konsep Hegemoni_Gramsci, 2018. .

[5] Jafar, "Wali Kota Bandar Lampung Herman HN Keluarkan Edaran tentang Penggunaan Siger," http://duajurai.co/2016/05/30/walikota-bandar-lampung-herman-hnkeluarkan-edaran-tentangpenggunaan-siger/, 2016.

[6]

"https://i2.wp.com/www.mondasireg ar.com/wpcontent/uploads/2015/07/IMG 7088$0 . j p g ? s s l=1 . "$.

"https://www.google.co.id/search?q =lambang+daerah+lampung\&safe=s trict\&hl=id\& $\mathrm{tbm}=$ isch\&source=iu\&ictx=1\&fir=0fJ wRsvSSG0jCM\%253A\%252C3719h t4j2l2nRM\%252C_\&vet=1\&usg=Al4 $-k T y-$

gTeOSs8xAEwJLgfYPtyL30EJg\&sa $=X \& v e d=2 a h U K E w i 40 a \_w 98 n j A h V H$ rY8KHVvBANIQ9QEwAHoECAkQB g\#img." . 